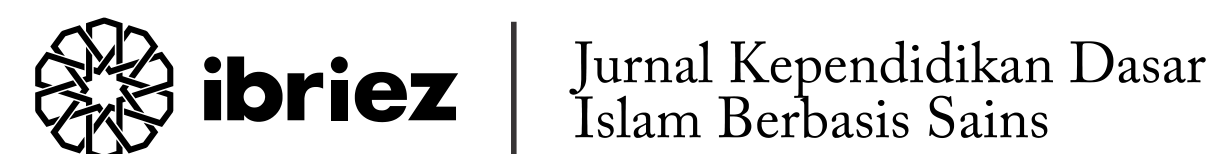

Volume. 5

Nomor. 1

Tahun. 2020

\section{Pengembangan Media Audio untuk Meningkatkan Kemampuan Menghubungkan Siklus Hidup dan Pelestariannya}

\author{
Yoga Marga Mahendra, Alfi Laila, Novi Nitya Santi \\ Prodi PGSD Universitas PGRI \\ Kediri \\ Surel : yogamarga27@gmail.com
}

\begin{abstract}
Abstrak
Penelitian ini bertujuan untuk mendeskripsikan: (1) need assesment atau analisis kebutuhan siswa dan guru terhadap pengembangan media audio visual; (2) kevalidan dari ahli media dari ahli materi; dan keefektifan model pengembangan media audio visual pada siklus makhluk hidup serta pelestarianya. Penitian ini merupakan jenis penelitian dan pengembangan (Reseacrh and Development). Model pengembangan penelitian mengacu pada prosedur ADDIE dengan 5 tahapan: (a) Analysis; (b) Design; (c) Development; (d) Implementation; (e) Evaluation. Metode pengumpulan data dengan observasi, wawancara, angket dan dokumentasi. Penilaian kevalidan media pembelajaran melibatkan lima dosen ahli materi dan ahli media. Hasil penenlitian inimenujukkan bahwa; 1) guru dan siswa sama-sama membutuhkan pengembangan media audio visual pada pembelajaran IPA di SDN Brenggolo 1,2) media audio visual berdasarkan dari hasil validasi ahli materi didapatkan skor 97,73 masuk dalam kategori sangat baik dan ahli desain media diperoleh nilai rata-rata 98,21 yang berarti bahwa media yang dikembangkan tersebut masuk dalam kategori sangat baik, dan 3) berdasarkan hasil uji coba skala kecil hasilnya adalah 72,50\% tergolong dalam kategori layak danselanjutnya pada uji coba skala besar menghasikan data 74,37\%, sehingga menyatakan media audio visual pada siklus hidup makhluk hidup serta peestarianya layak digunakan di SDN Brenggolo 1.

Kata Kunci: media audio visual, hubungan siklus hidup dan pelestariannya
\end{abstract}

\begin{abstract}
This study aims to describe: (1) need assessment or analysis of the needs of students and teachers for the development of audio-visual media; (2) validity from media experts from material experts; and the effectiveness of audio visual media development models in the cycle of living things and their conservationists. This research is a type of research and development (Research and Development). The research development model refers to the ADDIE procedure with 5 stages: (a) Analysis; (b) Design; (c) Development; (d) Implementation; (e) Evaluation. Data collection methods by observation, interview, questionnaire and documentation. Evaluation of the validity of instructional media involved five material expert lecturers and media experts. The results of this study indicate that; 1) teachers and students alike need the development of audio visual media in natural science learning at SDN Brenggolo 1,2) audio visual media based on the results of the validation of the material experts obtained a score of 97.73 included in the very good category and media design experts obtained the average value an average of 98.21 which means that the developed media is in the very good category, and 3) based on the results of small-scale trials the result is $72.50 \%$ classified in the feasible category and furthermore on the large-scale trial yields $74.37 \%$ data, so stated that audio-visual media in the life cycle of
\end{abstract}


living things and their conservationists is suitable for use in SDN Brenggolo 1

Keywords: media audio visual, hubungan siklus hidup dan pelestariannya

\section{A. PENDAHULUAN}

Perkembangan teknologi pada era modern telah memiliki perkembangan yang sangat pesat. Perkembangan teknologi telah memberikan dampak yang lebih baik pada era modern, baik dalam bidang komunikasi, transportasi, budaya, dan pendidikan. Pada bidang pendidikan, pemanfaatan teknologi, informasi, dan komunikasi digunakan untuk meningkatkan efisiensi dan efektivitas dalam pembelajaran ${ }^{1}$. Pada jenjang pendidikan Sekolah Dasar, teknologi juga sangat membantu guru dalam kegiatan pembelajaran yang dilakukan di sekolah, terutama pada materi yang membutuhkan beberapa format media demi ketercapaian tujuan pembelajaran, seperti halnya subtema aku dan cita-citaku.

Media adalah suatu sistem yang tidak bisa dilepaskan dengan pembelajaran. Media adalah segala bentuk yang dipergunakan untuk proses penyaluran informasi jadi dapat dikatakan bahwa media pembelajaran adalah alat yang digunakan guru untuk menyampaikan pesan pembelajaran kepada siswa, pentingnya media pada pembelajaran di kelas yaitu supaya tercapainya tujuan yang telah ditentukan ${ }^{2}$. Hal tersebut tentunya sangat dibutuhkan media pembelajaran yang

\footnotetext{
${ }^{1}$ Kebudayaan, Peraturan Menteri Pendidikan dan Kebudayaan No 22 Tahun 2016 Tentang Kompetensi Inti dan Kompetensi Dasar Pelajaran Pada Kurikulum 2013 Pada Pendidikan Dasar dan Pendidikan Menengah.

${ }^{2}$ Miarso, Definisi Teknologi Pendidikan.
}

mampu membantu peserta didik dalam memahami materi yang dipelajari lebih optimal. Salah satu media yang mampu membantu siswa pada pembelajaran di kelas berupa media berbasis teknologi informasi yang berupa media audio visual. Penerapan Teknologi Informasi di bidang pendidikan, khususnya dalam proses pembelajaran diyakini dapat memberikan pengaruh yang signifikan dalam meningkatkan kualitas pendidikan ${ }^{3}$. Penggunaan teknologi juga mampu membuat peserta didik melakukan kontrol terhadap aktivitas belajar, selain itu teknologi juga mampu mengintegrasikan beberapa komponen yang dapat mendukung aktivitas pembelajaran

Pada Kurikulum 2013 kelas IV semester 2, Tema 6 cita -citaku, Sub Tema 1 Aku dan Cita-citaku, terdapat Kompetensi Dasar 3.2 menghubungkan siklus hidup beberapa makhluk hidup serta mengaitkan dengan pelestarianya. Berdasarkan data observasi yang diperoleh melalui wawancara di SDN Brenggolo I, kelas IV yang dilaksanakan pada 4 april 2019, hasil wawancara peneliti yang dilakukan kepada beberapa siswa yaitu Pembelajaran IPA masih diajarkan meniru pada paradigma pendidikan lama "teacher centered". Konsep dari guru diberikan kepada siswa dan siswa menerima begitu saja sehingga

\footnotetext{
${ }^{3}$ Nurchaili, "Pengaruh Media Pembelajaran Berbasis Teknologi Informasi Dalam Proses Pembelajaran Kimia Terhadap Peningkatan Hasil Belajar Siswa."
} 
siswa tidak paham ${ }^{4}$, penyampaian materi pada Tema 6, Sub Tema 1, Kompetensi Dasar membandingkan siklus hidup serta mengaitkan dengan pelestariannya oleh guru kurang menarik karena dalam mengajar guru tidak menggunakan media pembelajaran tetapi guru hanya menggunakan buku ajar yang ada, selain itu interaksi antara guru dengan siswa masih kurang karena guru melakukan pembelajaran searah dan menyebabkan siswa kurang tertarik dengan kegiatan pembelajaran dan siswa cenderung pasif dalam pembelajaran. Oleh karena itu banyak siswa belum maksimal dalam memahami materi Komptensi Dasar 3.2 membandingkan siklus hidup beberapa jenis makhluk hidup serta upaya pelestariannya, dengan indikator 3.2.1 mengidentifikasi siklus makhluk hidup serta mengaitkan dengan pelestariannya, 3.2.2 membandingkan siklus makhluk hidup serta mengaitkan dengan pelestariannya. Pada pembelajaran IPA di Sekolah Dasar membutuhkan suatu inovasi baru yang mampu untuk mengaktifkan dan membuat proses pembelajaran menjadi lebih menyenangkan agar para siswa mampu untuk memahami materi yang dipelajari. Hal ini menuntut guru untuk dapat menjadi lebih kreatif dan inovatif dalam memilih media pembelajaran yang akan digunakan ${ }^{5}$. Kesuksesan dalam melakukan pembelajaran bisa

\footnotetext{
${ }^{4}$ Zuhaida, "Program Pembelajaran IPA Berbasis Masalah Untuk Menumbuhkan Metakognisi Siswa MTS Di Salatiga."

${ }^{5}$ Kusumawati, "Pengaruh Model Pembelajaran Kooperatif Dengan Snowball Throwing Terhadap Hasil Belajar IPA Pada Siswa Kelas IV SDN Bondrang Kecamatan Sawoo Kabupaten Ponorogo."
}

diakibatkan oleh beberapa faktor. Salah satunya adalah peran Guru dalam mengontrol kegiatan pembelajaran ${ }^{6}$. Dalam hal ini guru juga diharapkan menjadi model yang baik bagi siswa. Guru harus mempunyai akhlak dan perilaku yang mencerminkan nilai-nilai keluhuran berbudi pekerti. Hal ini sesuai dengan yang diajarkan dalam Islam yang terdapat dalam surat Al- Ahzab ayat 21 yang berbunyi:

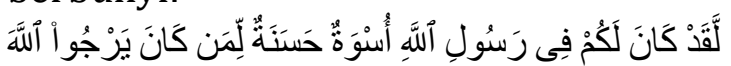

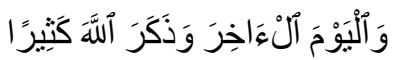

Artinya:

"Sungguh telah ada pada (diri) Rasulullah itu suri tauladan yang baik bagimu, (yaitu) bagi orang yang mengharap (rahmat) Allah dan (kedatangan) hari kiamat dan yang banyak mengingat Allah.(QS. Al- Ahzab ayat 21) .

Oleh karena itu, jika para peserta didik dapat memperoleh contoh yang baik dari gurunya, maka siswa tersebut pun akan termotivasi untuk melakukan kebaikan. Begitu pula sebaliknya, jika peserta didik terbiasa dengan contoh yang jelek, maka dapat dipastikan mereka akan termotivasi untuk melakukan keburukan.

Rendahnya hasil pembelajaran tersebut juga dibuktikan dengan hasil belajar siswa dibawah KKM 70, yaitu ratarata nilai kelas pada siklus hidup beberapa jenis makhluk hidup serta upaya pelestariannya 65 , berdasarkan wawancara dengan 20 siswa terdapat hasil yang menyatakan bahwa selama ini siswa hanya menghafal materi tanpa memahaminya sehingga ketika melewati

\footnotetext{
${ }^{6}$ Hadi, "Scaffolding Dalam Menyelesaikan Permasalahan KPK Dan FPB."
} 
materi tersebut siswa akan mudah lupa, oleh karena itu perlu sebuah alat/media yang dapat mempermudah siwa dalam mencapai Kompetensi Dasar 3.2 membandingkan siklus hidup beberapa makhluk hidup serta upaya pelestariannya

Berdasarkan permasalahan tersebut, maka dibutuhkan sebuah pengembangan media pembeajaran yang mampu memberikan pembelajaran yang kontekstual bagi peserta didik. Salah satu media pembelajaran yang sesuai dengan materi adalah siklus hidup beberapa jenis makhluk hidup serta upaya pelestariannya adalah media audio visual. Dimana media audio visual berperan sebagai alat bantu mengajar untuk mendapatkan tujuan pembelajaran. Menurut Azhar Arsyad" media audio visual adalah media memungkinkan sinyal audio dapat dikombinasikan dengan gambar bergerak untuk menyajikan audio dan visual yang berisi pesan-pesan pembelajaran baik yang berisi konsep, prinsip, prosedur, teori aplikasi pengetahuan untuk membantu pemahaman terhadap suatu materi pembelajaran"7. Jadi dapat disimpulkan bahwa media audio visual merupakan bahan pembelajaran tampak dengar (audio visual) yang dapat digunakan untuk menyampaikan pesan-pesan/ materi pelajaran, dikatakan tampak dengar karena unsur dengar (audio) dan unsure visual/ video (tampak dapat disajikan serentak).

Media audio visual mempunyai unsur gerak mampu menarik perhatian dan motivasi siswa dalam melaksanakan

\footnotetext{
${ }^{7}$ Arsyad, Media Pembelajaran.
}

kegiatan pembelajaran. Media audio visual mampu merangkum banyak kejadian dalam waktu yang lama dan menjadi lebih singkat dan jelas dengan disertai gambar dan suara yang dapat diulang-ulang dalam proses penggunaanya. Audio visual memiliki kelebihan yaitu membantu memahami pesan pembelajaran secara lebih bermakna tanpa terikat oleh bahan ajar lainnya. Dengan unsur gerak dan animasi yang dimiliki audio visual mampu menarik perhatian siswa lebih lama bila dibandingkan dengan media pembelajaran yang lainnya karena sesuai fungsinya Daryanto $^{8}$ (2013: 8) mengungkapkan bahwa media memiliki fungsi sebagai pembawa informasi dari sumber (guru) menuju penerima siswa. Hal tersebut juga di dukung oleh beberapa hasil penelitian yang menunjukkan bahwa hasil Penelitian ${ }^{9}$ : (1) media audiovisual memiliki kualitas baik, hal ini dapat dilihat dari hasil validasi oleh ahli media sebesar $85.25 \%$ ahli materi sebesar $87.37 \%$ masuk dalam kriteria sangat layak; (2) diteliti Oleh : Fuji Laksono10, Hasil Penelitian : Hasil Penelitian ini mendapat penilaian ahli materi dengan kategori sangat baik 4,62; (3) batas kriteria ketuntasan minimal 70. Yaitu $96 \%$ peserta didik mencapai standar kompetensi yang telah ditetapkan

\footnotetext{
8 Daryanto. 2015. Media Pembelajaran. Bandung: Sarana Tutorial Nurani Sejahtera

${ }^{9}$ Hikmah, "Pengembangan Multimedia (Audiovisual) Pembelajaran Matematika Pada Materi Bangun Ruang Bagi Siswa Kelas IV SD."

${ }^{10}$ Laksono, "Pengembangan Media Audio Visual Dalam Pembelajaran Budaya Hidup Sehat Khususnya Kebersihan Tangan Dan Kaki Pada Peserta Didik II SD Negeri Semen Kecamatan Windusari Kabupaten Magelan Provinsi Jawa Tengah."
} 
dan telah dinyatakan tuntas dan 4\% masih mendapat nilai kurang dari 70, ditetapkan dan telah dinyatakan tuntas dan 4\% masih mendapat nilai kurang dari $70^{11}$.

Berdasarkan hasil temuan dari tersebut maka pngembangan media audio visual perlu dilanjutkan pada Kompetensi Dasar 3.2 membandingkan siklus hidup beberapa jenis makhluk hidup serta mengaitkan dengan upaya pelestariannya.

Kelebihan media yang dikembangkan dibandingkan dengan media yang sudah ada yaitu adanya percakapan yang mengarah ke materi di dalam video tersebut, dimaksudkan agar menarik minat peserta didik dan peserta didik tidak akan bosan saat belajar sambil melihat video tersebut.

Setiap manusia yang lahir ke dunia ini pastinya mengalami proses perkembangan, sebagaimana Alloh telah berfirman dalam surat Al-Mukmin ayat 67

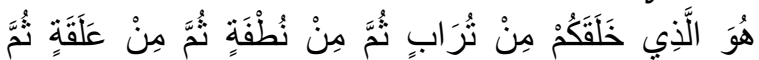

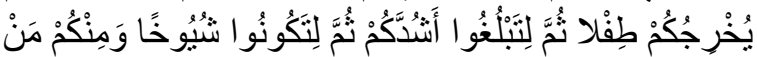

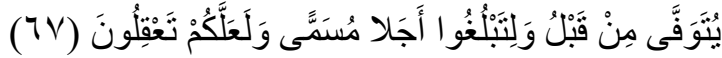
Artinya:

Dia-lah yang menciptakan kamu dari tanah kemudian dari setetes mani, sesudah itu dari segumpal darah, kemudian dilahirkannya kamu sebagai seorang anak, kemudian (kamu dibiarkan hidup) supaya kamu sampai kepada masa (dewasa), kemudian (dibiarkan kamu hidup lagi) sampai tua, di antara kamu ada yang diwafatkan sebelum itu. (kami perbuat demikian) supaya kamu sampai

\footnotetext{
${ }^{11}$ Widiastuti, "Pengembangan Video Pembelajaran Pewarnaan Serat Daun Suji Dengan Zat Warna Alam Untuk Siswa SMK N 5 Yogyakarta."
}

kepada ajal yang ditentukan dan supaya kamu memahaminya. ${ }^{12}$

Berdasarkan ayat tersebut manusia yang telah lahir ke dunia melalui tahapan pertumbuhan dan perkembangan. Anak usia sekolah dasar mengalami pertumbuhan dan perkembangan yang berada pada tahapan operasional konkret. Anak mulai menunjukkan perilaku belajar dengan menggunakan pemikiran-pemikiran yang difokuskan pada objek objek nyata atau konkret. Menurut Susanto ${ }^{13}$, tahap operasional konkret dimaknai sebagai berikut.

"Peserta didik sudah mulai memahami aspek-aspek kumulatif materi, mempunyai kemampuan memahami cara mengombinasikan beberapa golongan benda yang bervariasi tingkatnya. Selain itu peserta didik sudah mampu berfikir sistematis mengenai benda-benda dan peristiwa- peristiwa yang kongkret."

Berdasarkan uraian tersebut dapat diketahui bahwa anak usia sekolah dasar proses belajarnya sudah memasuki tahap operasional konkret, sehingga cara berfikir anak usia sekolah dasar lebih terorganisasi lagi pada tahap yang lebih konkret atau nyata untuk memahami materi yang dipelajari. Anak usia sekolah dasar sudah mampu berfikir secara logis tentang apa yang sedang dipelajari. Ada beberapa karakteristik anak diusia Sekolah Dasar yang perlu diketahui para guru, agar lebih mengetahui keadaan peserta didik khususnya ditingkat

\footnotetext{
${ }^{13}$ Susanto, Teori Belajar \& Pembelajaran Di Sekolah Dasar, 77.
} 
Sekolah Dasar, menurut Desmita ${ }^{14}$, karakeristik dan kebutuhan peserta didik dibahas sebagai berikut.

1. Karakteristik pertama anak SD adalah senang bermain.

Karakteristik ini menuntut guru SD untuk melaksanakan kegiatan pembelajaran yang mengandung unsur unsur permainan dan aktivitas fisik siswa. Pembelajaran yang melibatkan unsur permainan akan membuat siswa menjadi lebih tertarik dalam mengikuti kegiatan pembelajaran. Sedangkan menurut Djamarah dan Zain (2008), metode pembelajaran bermain peran memiliki kelebihan dan kekurangan, diantaranya yaitu: Djamarah ${ }^{15}$, metode pembelajaran bermain memiliki kelebihan dan kekurangan. Adapun kelebihan metode bermain adalah;

a. Dapat berkesan dengan kuat dan tahan lama dalam ingatan siswa, di samping menjadi pengalaman yang menyenangkan juga memberi pengetahuan yang melekat dalam memori otak.

b. Sangat menarik bagi siswa, sehingga memungkinkan membuat kelas menjadi dinamis dan antusias.

c. Membangkitkan gairah dan semangat optimisme dalam diri siswa serta menumbuhkan rasa kebersamaan.

Sedangkan kelemahan metode bermain adalah;

a. Metode bermain membutuhkan waktu yang relatif panjang atau banyak.

b. Membutuhkan kreativitas dan daya kreasi yang tinggi dari pihak guru

\footnotetext{
${ }^{14}$ Desmita, Psikologi Perkembangan, 35.

${ }^{15}$ Djamarah, Psikologi Belajar.
}

maupun siswa dan ini tidak semua guru memilikinya.

c. Kebanyakan siswa yang ditunjuk sebagai pemeran merasa malu untuk memerankan suatu adegan tertentu

2. Karakteristik yang kedua adalah senang bergerak.

Orang dewasa dapat duduk berjam-jam, sedangkan anak SD dapat duduk dengan tenang paling lama sekitar 30 menit. Oleh karena itu, dalam proses belajar mengajar hendaknya guru merancang kegiatan pembeiajaran yang berhubungan dengan aktifitas siswa yang memungkinkan siswa untuk berpindah tempat dan bergerak.

3. Karakteristik yang ketiga adalah anak senang bekerja dalam kelompok.

Karakteristik ini membawa implikasi bahwa guru harus merancang proses pembelajaran yang memungkinkan anak untuk bekeria atau beluiar dalam kelompok. Guru dapat meminta siswa untuk membentuk kelompok kecii dengan anggota 3-4 orang untuk mempeiajari atau menyelesaikan suatu tugas secara kelompok. Oleh sebab itu. guru dapat menggunakan media pembelajaran sebagai sarana penyampaian materi kepada siswa untuk lebih memahami.

\section{Karakteristik yang keempat.}

Anak SD senang merasakan atau melakukan sesuatu secara langsung, ditinjau dari teori perkembangan kognitif, anak SD memasuki tahap operasional konkret. Bagi anak usia sekolah dasar penjelasan guru tentang 
materi peiajaran akan iebih mudah dipahami siswa apabila siswa merasakan secara langsung. Dari pernyataan tersebut dapat disimpulkan bahwa anak pada usia Sekolah Dasar (SD) berada pada masa kanak-kanak tengah (6-9 tahun). Anak-anak pada usia Sekolah Dasar ini memiliki karakteristik senang bermain seperti kegiatan permainan dalam pembelajaran, senang bergerak atau berpindah-pindah tempat, senang bekerja dalam kelompokkeiompok dan senang melakukan secara langsung misalnya memberikan kesempatan kepada siswa untuk terlibat langsung dalam pembelajaran. Oleh sebab itu guru akan menggunakan media pembelajaran dalam proses kegiatan belajar mengajar sesuai dengan karakteristik anak usia sekolah dasar.

\section{B. METODE PENELITIAN}

Penelitian ini adalah penelitian dan pengembangan (Risert and Development). Model pengembangan yang digunakan dalam penelitian ini adalah model ADDIE, yang mana tahap pertama adalah melakukan analisis, analisis yang dilakukan dalam penelitian ini meliputi analisis kurikulum, analisis karakteristik peserta didik, dan analisis kubutuhan peserta didik. Tahap kedua yaitu desain, pada tahap ini adapun kegiatan yang dilaksanakan meliputi pembuatan instrument penilaian, menentukan $\mathrm{KI}, \mathrm{KD}$, Indikator, serta tujuan pembelajaran yang digunakan, membuat list barang dan merancang RPP. Tahap yang ketiga yaitu pengembangan produk, dalam pengembangan produk kegiatan yang dilaksanakan adalah menyiapkan konten beserta menggabungkannya dan melakukan validasi ahli media dan pembelajaran. Tahap keempat yaitu implementasi produk di sekolah, implementasi ini dilakukan untuk mengetahui kepraktisan dari produk yang dikembangkan melalui hasil penilaian angket yang diberikan oleh guru dan peserta didik. Tahap terakhir yaitu evaluasi, dalam model pengembangan ADDIE evaluasi dilakukan pada tiap tahapan

\section{HASIL PENELITIAN DAN PEMBAHASAN}

\section{Analisis data need assessment}

Data yang dihasilkan pada analisis kebutuhan di lapangan adalah data mentah yang berua skor minimal dan skor maksimal berdasarkan jumlah item yang ada di angket dan rentang pilihan gradasi yang telah disediakan dalam angket masing-masing komponen. Data skor mentah yang diperoleh dari jawaban responden terlebih dahulu dikonversi ke skala 100 kemudian dideskripsikan sesuai dengan masing-masing variabel. Untuk pedoman konversi sesuai dengan tabel 1 berikut.

Tabel 1. Pedoman Konversi

\begin{tabular}{|c|c|c|}
\hline No & Rentang Skor & Kategori \\
\hline 1 & $85-100$ & Sangat Baik \\
\hline 2 & $70-84$ & Baik \\
\hline 3 & $55-69$ & Cukup \\
\hline 4 & $40-54$ & Kurang \\
\hline 5 & $0-39$ & $\begin{array}{c}\text { Sangat } \\
\text { Kurang }\end{array}$ \\
\hline
\end{tabular}

1. Need Assessment

a. Siswa 
Urgensi Penggunaan Media Audio visual

\section{Menurut Siswa}

Tabel 2. Need assessment

pengembangan media Audio Visual

Responden Siswa

\begin{tabular}{|c|c|c|c|}
\hline $\begin{array}{l}\mathrm{N} \\
\mathrm{O}\end{array}$ & $\begin{array}{l}\text { Urgensi } \\
\text { Kebutuhan }\end{array}$ & $\begin{array}{l}\text { Jum } \\
\text { lah }\end{array}$ & $\begin{array}{l}\text { Prese } \\
\text { ntase }\end{array}$ \\
\hline 1 & $\begin{array}{l}\text { Saya lebih mudah } \\
\text { memahami } \\
\text { pelajaran setelah } \\
\text { guru } \\
\text { menggunakan } \\
\text { media } \\
\text { pembelajaran }\end{array}$ & 24 & $80 \%$ \\
\hline 2 & $\begin{array}{l}\text { Saya merasa } \\
\text { bosan jika } \\
\text { kegiatan belajar } \\
\text { mengajar tidak } \\
\text { menggunakan } \\
\text { media } \\
\text { pembelajaran }\end{array}$ & 30 & $\begin{array}{c}100 \\
\%\end{array}$ \\
\hline 3 & $\begin{array}{l}\text { Saya lebih } \\
\text { bersemangat } \\
\text { mengikuti } \\
\text { pelajaran saat } \\
\text { guru } \\
\text { menggunakan } \\
\text { media } \\
\text { pembelajaran }\end{array}$ & 21 & $75 \%$ \\
\hline 4 & $\begin{array}{l}\text { Saya tidak } \\
\text { merasakan } \\
\text { manfaat media } \\
\text { pembelajaran }\end{array}$ & 5 & $25 \%$ \\
\hline 5. & $\begin{array}{l}\text { Saya lebih rajin } \\
\text { belajar karena } \\
\text { media } \\
\text { pembelajaran } \\
\text { membuat saya } \\
\text { menyukai } \\
\text { pelajaran }\end{array}$ & 27 & $90 \%$ \\
\hline \multicolumn{2}{|c|}{ Jumlah } & & \\
\hline
\end{tabular}

b. Urgensi pengembangan media audio visual menurut guru.

Tabel 3. Urgensi Pengembangan

Media Audio Visual Menurut Guru

\begin{tabular}{|l|l|c|c|}
\hline $\begin{array}{l}\text { N } \\
\text { o }\end{array}$ & \multicolumn{1}{|c|}{$\begin{array}{c}\text { Urgensi } \\
\text { Kebutuhan }\end{array}$} & $\begin{array}{l}\text { Jum } \\
\text { lah }\end{array}$ & $\begin{array}{c}\text { Presen } \\
\text { tase }\end{array}$ \\
\hline 1 & $\begin{array}{l}\text { Saya } \\
\text { memanfaatkan } \\
\text { media } \\
\text { pembelajaran } \\
\text { audio visual }\end{array}$ & 5 & $25 \%$ \\
\hline 2 & $\begin{array}{l}\text { Saya pernah } \\
\text { membuat } \\
\text { sendiri media } \\
\text { pembelajaran } \\
\text { dan mengalami } \\
\text { banyak kendala }\end{array}$ & 5 & $25 \%$ \\
\hline 3 & $\begin{array}{l}\text { Sumber belajar } \\
\text { yang sangat } \\
\text { butuh } \\
\text { dikembangakan } \\
\text { segera adalah } \\
\text { media audio } \\
\text { visual }\end{array}$ & 20 & $100 \%$ \\
\hline 4 & $\begin{array}{l}\text { Pada materi } \\
\text { membandingkan } \\
\text { siklus beberpa } \\
\text { makhluk hidup } \\
\text { serta } \\
\text { mengaitkan } \\
\text { upaya } \\
\text { pelestarianya } \\
\text { membutuhkan } \\
\text { visualisasi objek } \\
\text { siklus beberpa } \\
\text { makhluk hidup } \\
\text { mengaitkan }\end{array}$ & 20 & $100 \%$ \\
\hline $\begin{array}{l}\text { Pada materi } \\
\text { membandingkan }\end{array}$ & 20 & $100 \%$ \\
\hline
\end{tabular}




\begin{tabular}{|l|l|l|l|}
\hline & $\begin{array}{l}\text { upaya } \\
\text { pelestarianya } \\
\text { membutuhkan } \\
\text { penejelasan } \\
\text { mendetail }\end{array}$ & & \\
\hline 6 & $\begin{array}{l}\text { Pada materi } \\
\text { yang bersifat } \\
\text { abstrak perlu } \\
\text { disajikan } \\
\text { visualisai objek }\end{array}$ & $100 \%$ \\
\hline 7 & $\begin{array}{l}\text { Siswa lebih } \\
\text { tertarik jika } \\
\text { belajar } \\
\text { menggunakan } \\
\text { media audio } \\
\text { visual }\end{array}$ & $90 \%$ \\
\hline Jumlah & & \\
\hline
\end{tabular}

\section{Validasi Produk Media Audio Visual}

Data yang diperoleh dari skala yang diberikan oleh ahli materi/isi ini menentukan kevalidan media audio visual Data kevalidan dianalisis menggunakan teknik analisi statistik deskriptif dengan menghitung presentase yang menggunakan rumus sebagai berikut ${ }^{16}$

$$
P=\frac{\sum^{x} \quad X 100 \%}{\sum^{x i}}
$$

rangan:

Kete

$\mathrm{P}=$ Presentase kevaldan ahli isi/materi

$\Sigma^{\mathrm{x}}=$ jumlah keseluruhan jawaban responden

$\Sigma^{\mathbf{x i}}=$ jumlah keseluruhan skor ideal dalam satu item

$100 \%=$ konstanta

Pedoman yang digunakan untuk

\footnotetext{
${ }^{16}$ Sugiyono, Metode Penelitian Pendidikan (Pendekatan Kuantitatif, Kualitatif, Dan R\&D).
}

memberikan makna dan pengambilan keputusan disajikan pada tabel 4 berikut.

Tabel 4. Pengambilan Keputusan Kualifikasi Validasi Produk Media Audio Visual

\begin{tabular}{|c|c|c|}
\hline $\begin{array}{c}\text { Pencapaian } \\
\text { (5) }\end{array}$ & Kualifiasi & Keteranga \\
\hline $90-100$ & Sangat valid & Tidak perlu direvisi \\
\hline $75-89$ & Valid & Sedikit revisi \\
\hline $65-75$ & Cukup valid & Direvisi secukupnya \\
\hline $55-64$ & Kurang valid & Banyak hal yang direvisi \\
\hline $0-54$ & $\begin{array}{c}\text { Sangat kurang } \\
\text { valid }\end{array}$ & Diulangi membuat produk \\
\hline \multicolumn{3}{|c}{} \\
\hline
\end{tabular}

Penilaian desain dilakukan oleh ahli desain terhadap tiga (3) komponen desain model pembelajaran, yaitu (1) Relevansi, (2) Hasil Penggunaan Bahan, dan (3) Pembelajaran. Penilaian dilakukan dengan cara memberikan skor satu sampai dengan empat yang mempresentasikan tanggapan, yaitu skor satu (1) Artinya tidak baik, skor dua (2) artinya kurang baik, skor (3) artinya baik, dan skor (4) artinya sangat baik. Hasil penelitian ahli desain tersebut disajikan pada Tabel 5

Tabel 5. Penilaian Ahli Materi

\begin{tabular}{|l|l|l|l|}
\hline No & Komponen & Nilai & Kualifikasi \\
\hline 1 & Relevansi & 100,00 & $\begin{array}{l}\text { Sangat } \\
\text { Baik }\end{array}$ \\
\hline 2 & $\begin{array}{l}\text { Hasil } \\
\text { Penggunaan } \\
\text { Bahan }\end{array}$ & 100,00 & $\begin{array}{l}\text { Sangat } \\
\text { Baik }\end{array}$ \\
\hline 3 & Pemblajaran & 93,75 & $\begin{array}{l}\text { Sangat } \\
\text { Baik }\end{array}$ \\
\hline $\begin{array}{l}\text { Rerata } \\
\text { Keseluruhan }\end{array}$ & 97,73 & $\begin{array}{l}\text { Sangat } \\
\text { Baik }\end{array}$ \\
\hline
\end{tabular}

Penilaian media dilakukan oleh ahli media terhadap tujuh (7) komponen media pembelajaran, yaitu (1) ketepatan 
gambar gambar yang digunakan pada sampul, (2) kesesuaian bahan dengan media / gambar yang digunakan, (3) kualitas gambar dalam uraian materi, (4) ketepatan penempatan gambar, (5) ketepatan ukurun gambar, (6) kualitas teks, dan (7) kualitas tabel Penilasan dilakukan dengan cara memberikan skor satu sampai dengan empat yang mempresentasikan tanggapan, yaitu skor satu (1) tidak dapat sesuai / tidak sesuai , skor dua (2) artinya karang baik / kurang sesuai, skor tiga (3) berarti baik / sesuai, dan skor empat (4) berarti sangat baik / sangat sesuai. Hasil Perkiraan ahli media yang disajikan pada Tabel 6.

Tabel 6 Penilaian Ahli Desain Media

\begin{tabular}{|l|l|l|l|}
\hline No & Komponen & Nilai & Kualifikasi \\
\hline 1 & $\begin{array}{l}\text { Ketepatan } \\
\text { ilustrasi } \\
\text { gambar yang } \\
\text { digunakan } \\
\text { pada cover }\end{array}$ & $\begin{array}{l}\text { Sangat } \\
\text { Baik }\end{array}$ \\
\hline 2 & $\begin{array}{l}\text { Kesesuaian } \\
\text { materi dengan } \\
\text { media/gambar } \\
\text { yang } \\
\text { digunakan }\end{array}$ & 100,00 & $\begin{array}{l}\text { Sangat } \\
\text { Baik }\end{array}$ \\
\hline 3 & $\begin{array}{l}\text { Kualitas } \\
\text { gambar dalam } \\
\text { uraian materi }\end{array}$ & 100,00 & $\begin{array}{l}\text { Sangat } \\
\text { Baik }\end{array}$ \\
\hline 4 & $\begin{array}{l}\text { Ketepatan } \\
\text { penempatan } \\
\text { gambar }\end{array}$ & 100,00 & $\begin{array}{l}\text { Sangat } \\
\text { Baik }\end{array}$ \\
\hline 5 & $\begin{array}{l}\text { Ketepatan } \\
\text { ukuran } \\
\text { gambar }\end{array}$ & 87,50 & Baik \\
\hline 6 & $\begin{array}{l}\text { Kualitas teks } \\
100,00\end{array}$ & $\begin{array}{l}\text { Sangat } \\
\text { Baik }\end{array}$ \\
\hline 7 & Kualitas tabel & 100,00 & Sangat \\
\hline
\end{tabular}

\begin{tabular}{|l|l|l|}
\hline & & Baik \\
\hline Rerata total & 98,21 & $\begin{array}{l}\text { Sangat } \\
\text { Baik }\end{array}$ \\
\hline
\end{tabular}

A. Pembahasan

1) Need Assessment pengembangan media visual menurut siswa dan guru

\section{a. Need Assessment Guru}

Berdasarkan data pada tabel dua urgensi penggunaan media audio visual dari 30 siswa yang mengisi angket terdapat 21 siswa (75\%) siswa lebih bersemangat mengikuti pelajaran saat guru menggunakan media audio visual dalam pembelajaran, sedangkan sisanya menjawab biasa-biasa saja. Hal ini memang gaya belajar masing-masing siswa berbeda anatara satu dengan yang lainya. Jika siswa gaya belajarnya tergolong kinestetik maka siswa cenderug tidak merasa bahwa media audio visual ini sebagai media yang bisa membangkitkan semangat belajarnya. Pada aspek peningkatan pemahaman pembelajaran setelah menggunakan media terdapat $80 \%$ atau 24 siswa yang berpendapat bahwa siswa ada peningkatan semangat belajarnya dan terdapt $100 \%$ atau 30 siswa yang merasa bosan jika pembelajaran tidak menggunakan medaia pembelahjaran sama sekali. Hal ini menujukkan bahwa keberfuangsian penggunaan media pembelajaran bisa maksimal ${ }^{17}$

\section{b. Need Assessment Guru}

Analisis kebutuhan berdasarkan

\footnotetext{
${ }^{17}$ Smaldino, Lowther, and Mims, Instructional Technology and Media for Learning 12th Edition.
} 
data tabel tiga dapat disimpulkan bahwa pemanfaatan media pembelajaran audio visual masih belum maksimal penggunaanya, hal ini dibuktikan hanya $25 \%$ guru yang pernah menggunakan medai tersebut, padalah untuk pembelajaran IPA pada materi membandingkan siklus beberpa makhluk hidup serta mengaitkan upaya pelestarianya membutuhkan visualisasi objek dan penjelasan secara detail serta lebih rinci, hal tersebut juga diakui oleh guru sebanyak 100\%. Dengan demikian, pengembangan media Audio visual memang sangat dibutuhkan.

Pengembangan media pembelajaran harus memperhatikan penggunaan berbagai alat indera ${ }^{18}$. Semakian banyak alat indera yang digunakan untuk menerima dan memproses informasi melalui pembelajaran di kelas maka semakin besar kemungkinan tujuan pembelajaran tersebut tercapai secara maksimal ${ }^{19}$. Disamping itu juga dalam pengembangan media pembelajaran juga harus memperhataikan aspek 4P yang meliputi pribadi kreatif, press/dorongan, proseskreatif, dan produk kreatif yang lebih difokuskan pada langkah proses keratif dengantahapan Persiapan,

\footnotetext{
${ }^{18}$ Hariyanti, “Pengaruh Persepsi Siswa Tentang Keterampilan Penggunaan Media Pembelajaran Oleh Guru PAI Terhadap Motivasi Belajar PAI Siswa Kelas VIII Di SMP Hasanuddin 6 Semarang."

${ }^{19}$ Arsyad, Media Pembelajaran.
}

inkubasi, iluminasi, dan verifikasi $^{20}$.

2) Kevalidan Pengembangan Media Audio Visual

Hasil analisi Tabel 5, data penilaian ahli desain media pembelajaran terhadap produk media audio visual yang dikembangkan dalam penelitian ini menunjukan bahwa respon ahli desain berada pada kategori sangat baik. Hal ini menjadi indikasi bahwa dari aspek desain media audio isual yang dikembangkan valid dan layak digunakan sebagai fasilitas pembelajaran.

Berdasarkan hasil penilaian ahli media pada tabel enam menunjukan bahwa hasil analisis data penilaian ahli media pembelajaran terhadap produk media audio visual yang dikembangkan dalam penelitian ini menurut respon ahli media berada pada kategori sangat baik. Hal ini mengindikasikan bahwa dari aspek media audio visual layak digunakan sebagai fasilitas pembelajaran.

\section{3) Keefektifan penggunaan media audio visual pada pmbelajaran IPA}

\section{a. Hasil uji coba skala kecil \\ Berdasarkan hasil uji coba yang dilakukan pada skala kecil menggunakan angket respon siswa dengan skala likert yang dilakukan pada 1 orang siswa yang memiliki}

${ }^{20}$ Laila and Sahari, "PENINGKATAN KREATIVITAS
MAHASISWA DALAM PEMANFAATAN BARANG-
BARANG BEKAS PADA MATA KULIAH MEDIA
PEMBELAJARAN." 
kompetensi paling rendah diperoleh skor total dari 10 butir instrument adalah 29 atau dengan persentase kelayakan adalah 72,50\%. Dengan demikian media video dapat dinyatakan layak dan dapat digunakan dalam uji coba lapangan skala besar.

\section{b. Hasil Uji Coba Skala Besar}

Kelayakan media video dilakukan dengan uji coba skala besar merupakan uji tahap akhir dalam pengembangan media video mata pelajaran. Kelayakan media audio visual dilakukan dengan uji coba skala besar merupakan uji tahap akhir dalam pengembangan media audio visual pada materi siklus hidup maklhuk hidup serta pelestariannya.

Berdasarkan

hasil

penerapan media audio visual pada uji coba luas yang diterapkan kepada 4 siswa (responden) digunakan untuk menilai produk media dari aspek secara keseluruhan, maka diperoleh skor keseluruhan responden adalah 119 dengan persentase kelayakan adalah 74,73\%. Dengan demikian dapat diinterpretasikan bahwa media video mata pelajaran keterampilan menyulam termasuk dalam kategori "layak" dan dapat digunakan sebagai media pembelajaran di SDN Brenggolo I.

Hasil dari data tersebut maka dapat disimpulkan bahwa media audio visual pada materi siklus hidup makhluk hidup serta pelestariannya ini layak digunakan dalam proses pembelajaran serta dapat diproduksi sebagai media pembelajaran bagi siswa klas IV SDN Brenggolo I

\section{B. KESIMPULAN DAN IMPLIKASI}

\section{Kesimpulan}

Berdasarkan hasil penelitian dan pengembangan Media Audio Visual penelitian ini menggunakan model pengembangan tipe ADDIE, dengan tingkat kevalidan produk sebesar $98 \%$ oleh validator ahli media dan $81 \%$ oleh validator ahli pembelajaran.

\section{Implikasi}

Berdasarkan hasil penelitian, implikasi ini adalah sebagai berikut:

1. Media Audio Visual pada materi siklus hidup makhluk hidup mampu meningkatkan hasil pembelajaran yang kontekstual bagi peserta didik.

2. Media Audio Visual mampu membantu peserta didik dalam mencapai tujuan pembelajaran pada KD 3.2 membandingkan siklus hidup beberapa jenis makhluk hidup serta mengaitkan dengan upaya pelestariannya.

\section{Saran}

1. Dalam menerapkan produk yang dikembangkan, maka dibutuhkan LCD proyektor agar pembelajaran dapat dilaksanakan.

2. Dalam proses pembelajaran diharapkan penelitian selanjutnya mampu mengatur alokasi waktu dengan baik dan telah menyiapkan produk yang 
dikembangkan sebelum pembelajaran dilaksanakan.

3. Peneliti menyarankan untuk penelitian selanjutnya agar mampu memberikan lebih banyak informasi mengenai siklus hidup makhluk hidup dengan media yang lebih inovatif dan menarik.

\section{DAFTAR PUSTAKA}

Arsyad, Azhar. Media Pembelajaran. Jakarta: Raja Grafindo Persada, 2017.

Desmita. Psikologi Perkembangan.

Bandung: Remaja Rosdakarya, 2012.

Djamarah, Syaiful Bahri. Psikologi Belajar. Jakarta: Rineka Cipta, 2002.

Hadi, Sofwan. "Scaffolding Dalam

Menyelesaikan Permasalahan KPK

Dan FPB." Ibriez : Jurnal

Kependidikan Dasar Islam Berbasis

Sains 1, no. 1 (December 31, 2016):

141-48.

https://doi.org/10.21154/IBRIEZ.V1

I1.16.

Hariyanti, Mifta Lestari. "Pengaruh

Persepsi Siswa Tentang

Keterampilan Penggunaan Media

Pembelajaran Oleh Guru PAI

Terhadap Motivasi Belajar PAI Siswa

Kelas VIII Di SMP Hasanuddin 6

Semarang." UIN Walisongo

Semarang, 2013.

Hikmah, Nurul. "Pengembangan

Multimedia (Audiovisual)

Pembelajaran Matematika Pada

Materi Bangun Ruang Bagi Siswa

Kelas IV SD." Nurul Hikmah. Jurnal

Pendas Mahakam. Vol. 2, 2017.

https://jurnal.fkip-

uwgm.ac.id/index.php/pendasmahak am/article/view/96.

Kebudayaan, Kementerian Pendidikan dan. Peraturan Menteri Pendidikan

dan Kebudayaan No 22 Tahun 2016

Tentang Kompetensi Inti dan

Kompetensi Dasar Pelajaran Pada

Kurikulum 2013 Pada Pendidikan

Dasar dan Pendidikan Menengah (2016).

Kusumawati, Naniek. "Pengaruh Model

Pembelajaran Kooperatif Dengan

Snowball Throwing Terhadap Hasil

Belajar IPA Pada Siswa Kelas IV SDN

Bondrang Kecamatan Sawoo

Kabupaten Ponorogo." Ibriez : Jurnal

Kependidikan Dasar Islam Berbasis

Sains 2, no. 1 (June 1, 2017): 1-12.

https://doi.org/10.21154/ibriez.v2i

1.19.

Laila, Alfi, and Sutrisno Sahari.

"PENINGKATAN KREATIVITAS

MAHASISWA DALAM

PEMANFAATAN BARANG-BARANG

BEKAS PADA MATA KULIAH MEDIA

PEMBELAJARAN." Jurnal Pendidikan

Dasar Nusantara 1, no. 2 (2016).

http://efektor.unpkediri.ac.id.

Laksono, Fuji. "Pengembangan Media

Audio Visual Dalam Pembelajaran

Budaya Hidup Sehat Khususnya

Kebersihan Tangan Dan Kaki Pada

Peserta Didik II SD Negeri Semen

Kecamatan Windusari Kabupaten

Magelan Provinsi Jawa Tengah."

Universitas Muhamadiyah Magelang, 2018.

Miarso, Yusuf Hadi. Definisi Teknologi

Pendidikan. 7th ed. Jakarta: Raja

Grafindo Persada, 1994.

Nurchaili. "Pengaruh Media Pembelajaran

Berbasis Teknologi Informasi Dalam

Proses Pembelajaran Kimia

Terhadap Peningkatan Hasil Belajar

Siswa." Jurnal Pendidikan Dan

Kebudayaan 16, no. 6 (November 10, 2010): 648.

https://doi.org/10.24832/jpnk.v16i 6.493.

Smaldino, Sharon E, Deborah L Lowther, 
and Clif Mims. Instructional

Technology and Media for Learning 12th Edition, 2019.

https://lccn.loc.gov/2017015584.

Sugiyono. Metode Penelitian Pendidikan

(Pendekatan Kuantitatif, Kualitatif,

Dan R\&D). Bandung: Alfabeta, 2013.

Susanto, A. Teori Belajar \& Pembelajaran

Di Sekolah Dasar. Jakarta: Kencana

Pranedamedia, 2014.

Widiastuti, Septi. "Pengembangan Video

Pembelajaran Pewarnaan Serat Daun

Suji Dengan Zat Warna Alam Untuk

Siswa SMK N 5 Yogyakarta."

Universitas Gajah Mada, 2018.

Zuhaida, Anggun. "Program Pembelajaran

IPA Berbasis Masalah Untuk

Menumbuhkan Metakognisi Siswa

MTS Di Salatiga." Ibriez : Jurnal

Kependidikan Dasar Islam Berbasis

Sains 2, no. 2 (December 30, 2017):

133-42.

https://doi.org/10.21154/ibriez.v2i

2.30 . 